\title{
Eutectic Freeze Crystallization process for the treatment of ternary textile wastewater concentrates
}

\author{
Buhle S. Manana (Buhle.Manana@alumni.uct.ac.za) \\ P. Nembudani \\ Marcos Rodriguez-Pascual (marcos.rodriguezpascual@uct.ac.za) \\ Supervisor: Marcos Rodriguez-Pascual \\ Department: Crystallization and Precipitation Research Unit, \\ Department of Chemical Engineering
}

\begin{abstract}
Textile wastewaters contain high levels of sodium chloride $(\mathrm{NaCl})$ and sulphate $\left(\mathrm{Na}_{2} \mathrm{SO}_{4}\right)$ salts. Conventional water treatment uses evaporative crystallization (EC) which is an energy intensive process and is only effective in recovering pure water and a mixed sulphate-chloride salt. The mixed salt is contaminated with hardness and colour and cannot be recycled within the plant. This research investigates the technical applicability of using Eutectic Freeze Crystallization (EFC) in the recovery of water (as ice) and $\mathrm{Na}_{2} \mathrm{SO}_{4}$ salt. The effect of varying the operating temperature on the recovery and the purity of the ice and the salt was investigated using a synthetic textile wastewater stream containing $1.4 \quad w t \% \quad \mathrm{Na}_{2} \mathrm{SO}_{4}$ and $4.5 \mathrm{wt} \% \mathrm{NaCl}$. Thermodynamic modelling software predicted that the nucleation temperature of ice and $\mathrm{Na}_{2} \mathrm{SO}_{4}$ to be $-3.1{ }^{\circ} \mathrm{C}$ and for $\mathrm{NaCl},-21.6{ }^{\circ} \mathrm{C}$. The recovery of ice was predicted to be $49 \%$ and $79 \%$ for $\mathrm{Na}_{2} \mathrm{SO}_{4} .10 \mathrm{H}_{2} \mathrm{O}$ at $-6.5^{\circ} \mathrm{C}$. Experimental validation, limited to operating temperatures above $-7^{\circ} \mathrm{C}$, showed a cumulative recovery of $42 \%$ of ice with $94 \%$ purity and $51.3 \%$ recovery with $98 \%$ purity for $\mathrm{Na}_{2} \mathrm{SO}_{4} \cdot 10 \mathrm{H}_{2} \mathrm{O}$ at $-6.5^{\circ} \mathrm{C}$. Sulphate analysis of the residual mother liquor at this temperature showed that $8.6 \mathrm{~g}$ of $\mathrm{Na}_{2} \mathrm{SO}_{4} \cdot 10 \mathrm{H}_{2} \mathrm{O}$ was entrapped within ice crystals, thus reducing the recovery of $\mathrm{Na}_{2} \mathrm{SO}_{4} \cdot 10 \mathrm{H}_{2} \mathrm{O}$ and the purity of ice. EFC is technically applicable for the recovery of ice and a single salt in a ternary system, however separation of the two phases is problematic due to high ice formation. The stream should first be treated with multistage Reverse Osmosis before EFC, so as to concentrate the stream and reduce ice formation.
\end{abstract}

Keywords: Eutectic Freeze Crystallisation; textile wastewater; sodium sulphate recovery 


\section{Introduction}

Textile production is an industry that consumes large volumes of water; approximately 200 litres of water are required to produce $1 \mathrm{~kg}$ of finished textiles (Parvathi, et al., 2009). Ultimately, this results in the generation of large volumes of wastewater contaminate with dyes, salts and traces of other impurities. Although the composition of the wastewater is area specific, they usually contain sodium sulphate (Na2SO4) and sodium chloride $(\mathrm{NaCl})$ which is added during the dyeing process as the salts drive the dye onto the fabric. Conventional wastewater treatment techniques involve sequential treatment using reverse osmosis (RO), adiabatic chilling and evaporative crystallisation (Hussain, 2012). This treatment technique can only recover pure water; however pure separate salts cannot be recovered from ternary system as they form a mixed salt which is contaminated with hardness and colour (Hussain, 2012).Eutectic Freeze Crystallization (EFC) is a novel method of treating concentrates to recover pure water and pure separate salts. The heat of fusion of ice ( $333 \mathrm{~kJ} / \mathrm{kg}$ ) is six times less than the heat of vaporisation of water $(2257 \mathrm{~kJ} / \mathrm{kg})$, therefore the energy required to recover water as ice is considerably less than that required to separate it by evaporation.

The principle of the EFC process is that when a saturated solution is slowly cooled below the freezing point line, ice crystals start to form and rise to surface, while the salt becomes concentrates in the remaining solution and eventually crystallizes out at the eutectic temperature (Genceli, et al., 2005). The two solid phases can be separation using gravitation separation due to gravity differences of the order of 1000 $\mathrm{kg} / \mathrm{m}^{3} . \mathrm{In}$ a ternary system [salt 1 (S1), salt 2 (S2), water], there are regions where ice coexists with solid S1 (pseudo-eutectic point 1), ice with solid S2 (pseudo-eutectic point 2) and ice with both solid S1 and S2, which is the ternary eutectic point. A sequential EFC process can theoretically be operated along the first eutectic line to recover the first salt and then along the second line to recover the second salt (Lewis, et al., 2010a). 
This paper investigated the technical feasibility of EFC in treating a synthetic ternary wastewater stream containing $\mathrm{Na}_{2} \mathrm{SO}_{4}$ and $\mathrm{NaCl}$, for the recovery of pure water and pure $\mathrm{Na}_{2} \mathrm{SO}_{4}$. This was done by investigating the effect of operating temperatures on the recovery and purity of water and $\mathrm{Na}_{2} \mathrm{SO}_{4}$. This arises due to an and interest in replacing the EC unit with an EFC unit as it has the potential of being more efficient in treatment of ternary systems and requires less energy resulting in lower operating costs.

\section{Materials and experiments}

\section{Composition of Wastewater Stream}

A synthetic wastewater stream was prepared using information obtained from a textile company in Tamil Nadu (India) and is shown below in Table 1 below.

Table 1: Composition of textile wastewater stream as provided in project brief

\begin{tabular}{|l|l|l|l|}
\hline & $\begin{array}{l}\text { RO concentrate } \\
\text { quality Details }\end{array}$ & \multicolumn{2}{|c|}{ Input into OLI } \\
\hline Parameters & $\begin{array}{l}\text { Provided } \\
\text { information }\end{array}$ & Parameters & $\begin{array}{l}\text { Input into } \\
\text { system }\end{array}$ \\
\hline pH value & 7 to 8 & $\mathrm{pH}$ value & 8 \\
\hline TDS (mg/l) & 50000 to 60000 & TDS $(\mathrm{mg} / \mathrm{l})$ & 60000 \\
\hline $\begin{array}{l}\text { Calcium } \\
\text { hardness, } \mathrm{CaCO}_{3} \\
\text { (mg/l) }\end{array}$ & 60 to 100 & $\mathrm{Ca}^{2+}(\mathrm{mg} / \mathrm{l})$ & 40 \\
\hline $\begin{array}{l}\text { Magnesium hardness, } \\
\text { CaCO }\end{array}{ }_{3}(\mathrm{mg} / \mathrm{l})$ & 40 to 60 & $\mathrm{Mg}^{2+}(\mathrm{mg} / \mathrm{l})$ & 14.6 \\
\hline${\mathrm{Chloride}, \mathrm{Cl}^{-}(\mathrm{mg} / \mathrm{l})}^{2-}$ & 23000 to 28000 & Chloride, $\mathrm{Cl}^{-}(\mathrm{mg} / \mathrm{l})$ & 28000 \\
\hline Sulphate, $\mathrm{SO}_{4}{ }^{2-}(\mathrm{mg} / \mathrm{l})$ & 5000 to 10000 & Sulphate, $\mathrm{SO}_{4}{ }^{2-}$ & 10000 \\
\hline
\end{tabular}




\begin{tabular}{|c|c|c|c|}
\hline & & $(\mathrm{mg} / \mathrm{l})$ & \\
\hline Total Silica $\mathrm{SiO}_{2}(\mathrm{mg} / \mathrm{l})$ & 90 to 110 & $\begin{array}{l}\text { Total Silica } \mathrm{SiO}_{2} \\
(\mathrm{mg} / \mathrm{l})\end{array}$ & 110 \\
\hline COD & 1000 to 1200 & COD & 1200 \\
\hline Sodium as $\mathrm{Na}(\mathrm{mg} / \mathrm{l})$ & 19500 to 23000 & $\begin{array}{l}\text { Sodium as } \mathrm{Na}^{+} \\
(\mathrm{mg} / \mathrm{l})\end{array}$ & 23000 \\
\hline Total Iron as Fe (mg/l) & $0.5-0.8$ & Iron as $\mathrm{Fe}^{3+}(\mathrm{mg} / \mathrm{l})$ & 0.8 \\
\hline $\begin{array}{l}\text { Bicarbonates, } \mathrm{CaCO}_{3} \\
(\mathrm{mg} / \mathrm{l})\end{array}$ & 1500 to 2000 & $\mathrm{HCO}_{3}^{-}(\mathrm{mg} / \mathrm{l})$ & 1639 \\
\hline
\end{tabular}

In order to prepare a synthetic solution which would closely represent the actual stream, the thermodynamic modelling software OLI Stream Analyser was used to conduct a water analysis and a stream analysis. This is computer software that uses a thermodynamic modelling database, thermodynamic framework and supporting numerical computation to simulate the chemical and phase behaviour of aqueous-based systems (OLI Systems, 2011). The water analysis uses MSE $\left(\mathrm{H}_{3} \mathrm{O}+\right.$ ion) thermodynamic framework and the data shown in Table 1 to resolve the stream and identify the dominant species in solution which should be added to solution in order to synthesis with a composition similar to that shown Table 1. The dominant species were found to be sodium sulphate, sodium chloride, silicon dioxide, iron carbonate and calcium carbonate.

The stream analysis tool was then used to investigate the behaviour of these species in a temperature survey between 25 and $-25{ }^{\circ} \mathrm{C}$. The temperature survey showed that the only species that would be in the solid phase at temperatures lower than the nucleation of water (as ice) at $-3^{\circ} \mathrm{C}$, The solid salts are recovered in hydrated forms $\left(\mathrm{Na}_{2} \mathrm{SO}_{4} \cdot 10 \mathrm{H}_{2} \mathrm{O}\right.$ and $\left.\mathrm{NaCl} \cdot 2 \mathrm{H}_{2} \mathrm{O}\right)$ as this is the most stable form at lower temperatures. Therefore all other species were eliminated from the synthetic stream as they would not nucleate out of solution at the temperatures under investigation. Silicon dioxide was eliminated from this system, as it became more soluble in water at lower 
temperatures. This resulted in a simplified stream with the composition shown in Table 2 below.

\section{Experimental work}

Experiments were carried out to investigate the effect of temperature on recovery and purity of ice and $\mathrm{Na}_{2} \mathrm{SO}_{4} \cdot 10 \mathrm{H}_{2} \mathrm{O}$.

Table 2: Composition of synthetic stream and operating conditions for experiments

\begin{tabular}{|c|c|c|c|}
\hline Number & $\begin{array}{l}\text { Composition (wt } \\
\%)\end{array}$ & $\begin{array}{l}\text { Operating } \\
\text { Temperature } \\
\left({ }^{\circ} \mathrm{C}\right)\end{array}$ & Conditions \\
\hline 1 & \multirow{3}{*}{$\begin{array}{l}1.4 \text { wt } \% \mathrm{Na}_{2} \mathrm{SO}_{4} \\
4.5 \mathrm{wt} \% \mathrm{NaCl}\end{array}$} & -3.6 & \multirow{3}{*}{$\begin{array}{l}\text { - Batch operated, batch } \\
\text { time of } 3 \text { hours after } \\
\text { seeding } \\
\text { - Cooling rate of } 1^{\circ} \mathrm{C} \text { every } \\
10 \text { minutes } \\
\text { - } \text { Seeding with } 1 \mathrm{~g} \text { ice and } \\
1 \mathrm{~g} \mathrm{Na}_{2} \mathrm{SO}_{4} \cdot 10 \mathrm{H}_{2} \mathrm{O} \text { at } \\
\text { once operating } \\
\text { temperature is reached } \\
\text { - } \text { Product settling time of } \\
30 \text { minutes with gentle } \\
\text { agitation }\end{array}$} \\
\hline 2 & & -4.9 & \\
\hline 3 & & -6.5 & \\
\hline
\end{tabular}

\section{Solution Preparation}

Synthetic textile waste water solutions were prepared using anhydrous analytical grade salts. Weighed quantities of anhydrous sodium sulphate and sodium chloride salts were dissolved in de-ionised water to form nine $1 \mathrm{~L}$ solutions to allow for each experiment to be conducted in triplicate at every temperature. A magnetic stirrer was used to obtain a homogeneous solution. 


\section{Experimental set-up and operation}

Experimental work was conducted in 1.5L agitated jacketed glass crystalliser, a 4 blade impeller was used for agitation at a speed of $400 \mathrm{rpm}$. Cooling was achieved using Kyro-40 which was supplied using a MRC BL-30 thermostatic unit. A Testo 174/144 temperature logger with built in software was connected to four PT-100 temperature sensors, and was used to monitor the temperature of the system. The temperature sensors were placed in four points; at the inlet and outlet of the coolant, inside the crystallizer to monitor the temperature of the solution and once outside the crystalliser to monitor the temperature of the room. The temperature of the room was kept constant at $-4{ }^{\circ} \mathrm{C}$. For filtration of the ice product, filtration was done under vacuum using a vacuum pump connected to a 1 filtration flask and Buchner funnel, using filter paper with a size of $110 \mu \mathrm{m}$. A $500 \mathrm{~mL}$ Millipore glass funnel with cellulose filter paper was used to filter out the salt product. Samples were analysed for purity using a Dionex ion chromatographer.

\section{Results and Discussion}

\section{Stream Analysis for the prediction of nucleation temperatures using Thermodynamic modelling}

An analysis of the synthetic stream was conducted using OLI Stream Analyser in order to model the behaviour of the system at different operating temperatures and predict the nucleation temperatures and recoveries, shown in Figure 1 below.

Figure 1 presents the salt recoveries as a function of temperature. The reported eutectic temperature for a binary $\mathrm{Na}_{2} \mathrm{SO}_{4} .10 \mathrm{H}_{2} \mathrm{O}$-water system is $-1.2{ }^{\circ} \mathrm{C}$ and $3.8 \mathrm{wt} \%$ (Vaessen, 2003) and for a binary $\mathrm{NaCl} .2 \mathrm{H}_{2} \mathrm{O}$-water system is $-21{ }^{\circ} \mathrm{C}$ and $23.3 \mathrm{wt} \%$ (Chemguide, 2014). However the interactions between the ions (common ion effect) of the two salts in solution results in depressed nucleation temperatures. From Figure 1, the solution only reaches supersaturation at $-3.1{ }^{\circ} \mathrm{C}$ and the first ice and $\mathrm{Na}_{2} \mathrm{SO}_{4} \cdot 10 \mathrm{H}_{2} \mathrm{O}$ crystals are observed. The model predicted that $\mathrm{Na}_{2} \mathrm{SO}_{4} \cdot 10 \mathrm{H}_{2} \mathrm{O}$ and ice would nucleate 
out at the same temperature implying that the system initially had a pseudo-eutectic composition. $\mathrm{NaCl} .2 \mathrm{H}_{2} \mathrm{O}$ nucleates out of solution at $-21.6{ }^{\circ} \mathrm{C}$, however the experimental work is limited to temperatures above $-6.5^{\circ} \mathrm{C}$ due to equipment and time constraints.

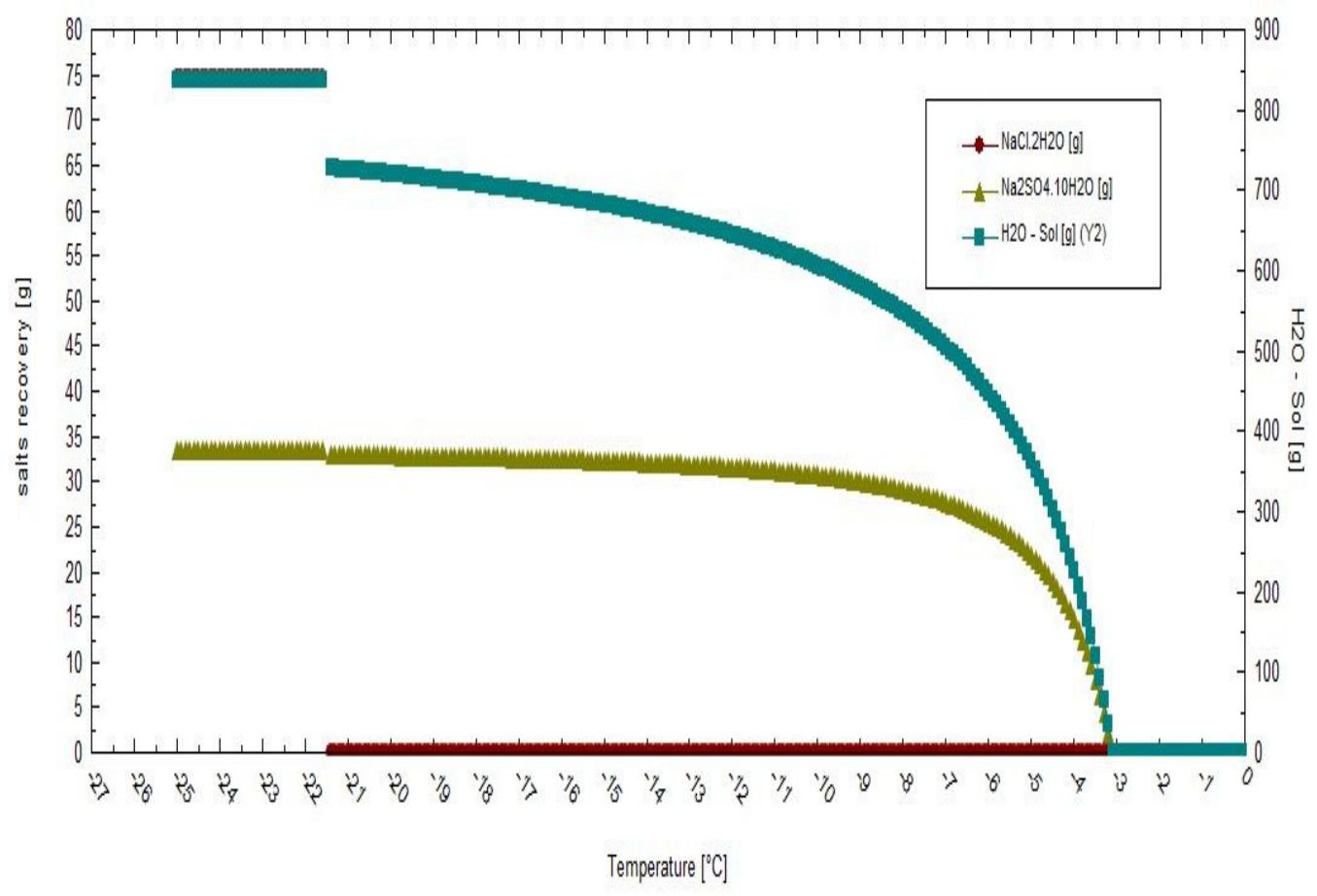

Figure 1: Salt and ice crystallization at varying temperatures as predicted by Thermodynamic modelling

The model presented in Figure 1 accounts solely for the thermodynamics of the solution and shows the maximum possible recovery at equilibrium. However, in reality, the recoveries are also limited by kinetics of crystallisation which is time dependent and experimental environment and the effectiveness of the gravitational separation. Therefore it is expected that the experimental results will be slightly less than but comparable to that predicted by the model.

\section{Experimental Data}

\section{Overall recovery of ice and $\mathrm{Na}_{2} \mathrm{SO}_{4.10 \mathrm{H}_{2} \mathrm{O}}$}


The mass balance was obtained by weighing the mass of the products obtained at the different operating temperatures and is shown in Figure 2 below.

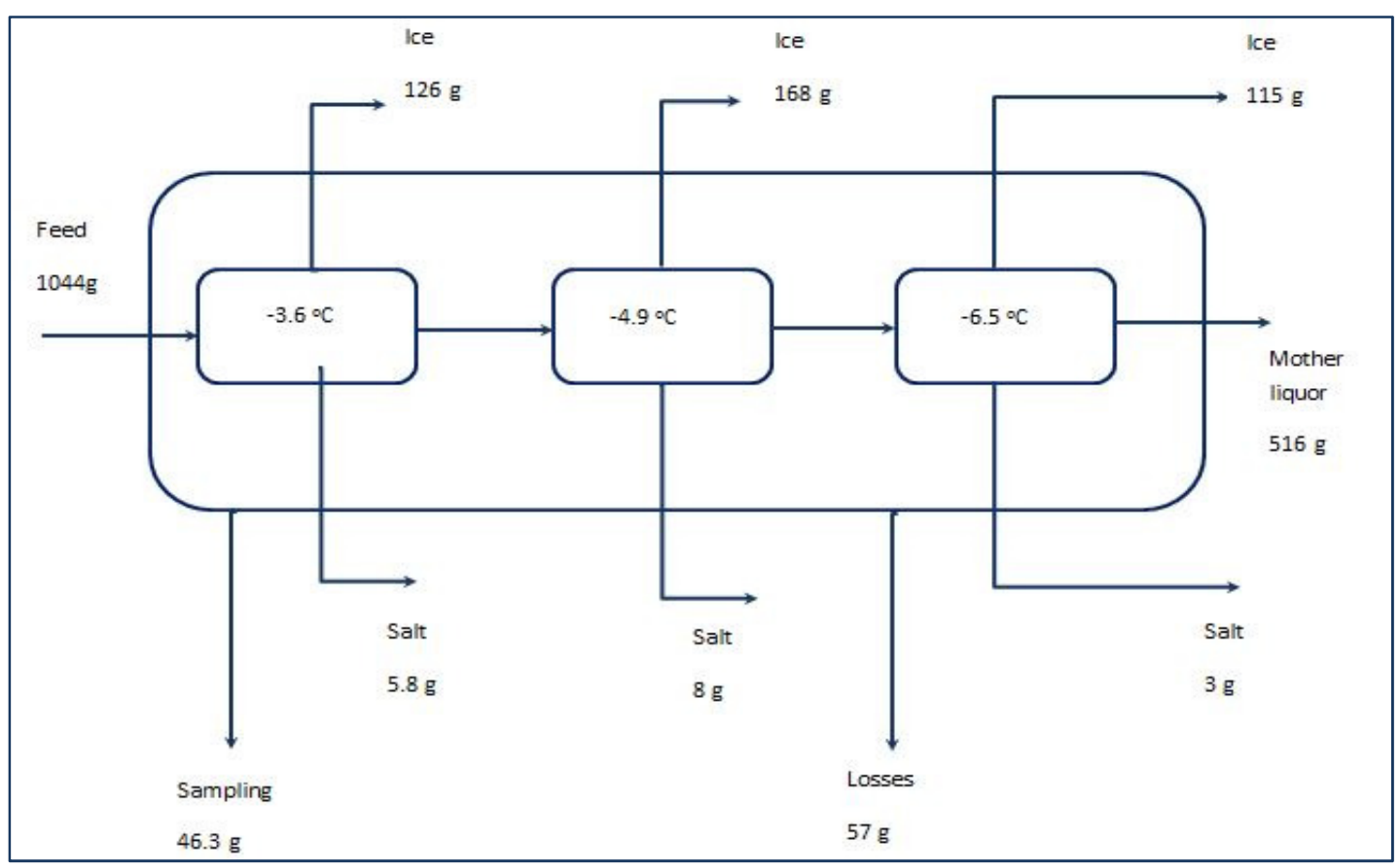

Figure 2: Mass balance over crystallizer

From Figure 2, the cumulative amount of ice recovered at the last operating temperature $\left(-6.5^{\circ} \mathrm{C}\right)$ was $409 \mathrm{~g}$ and the amount of $\mathrm{Na}_{2} \mathrm{SO}_{4} \cdot 10 \mathrm{H}_{2} \mathrm{O}$ was $17 \mathrm{~g}$. The cumulative amount recovered increases with decreasing temperature, however the amount of products recovered at every temperature is dependent on the supersaturation ratio at that temperature (Myerson, et al., 2002).Therefore, at every temperature, there is a maximum amount of product that can be recovered; decreasing the temperature increases the supersaturation ratio thus allowing for higher product recovery.

\section{Cumulative recovery of ice}

Figure 3 shows the cumulative recovery of ice at varying temperatures, both experimentally and from the thermodynamic modelling. 


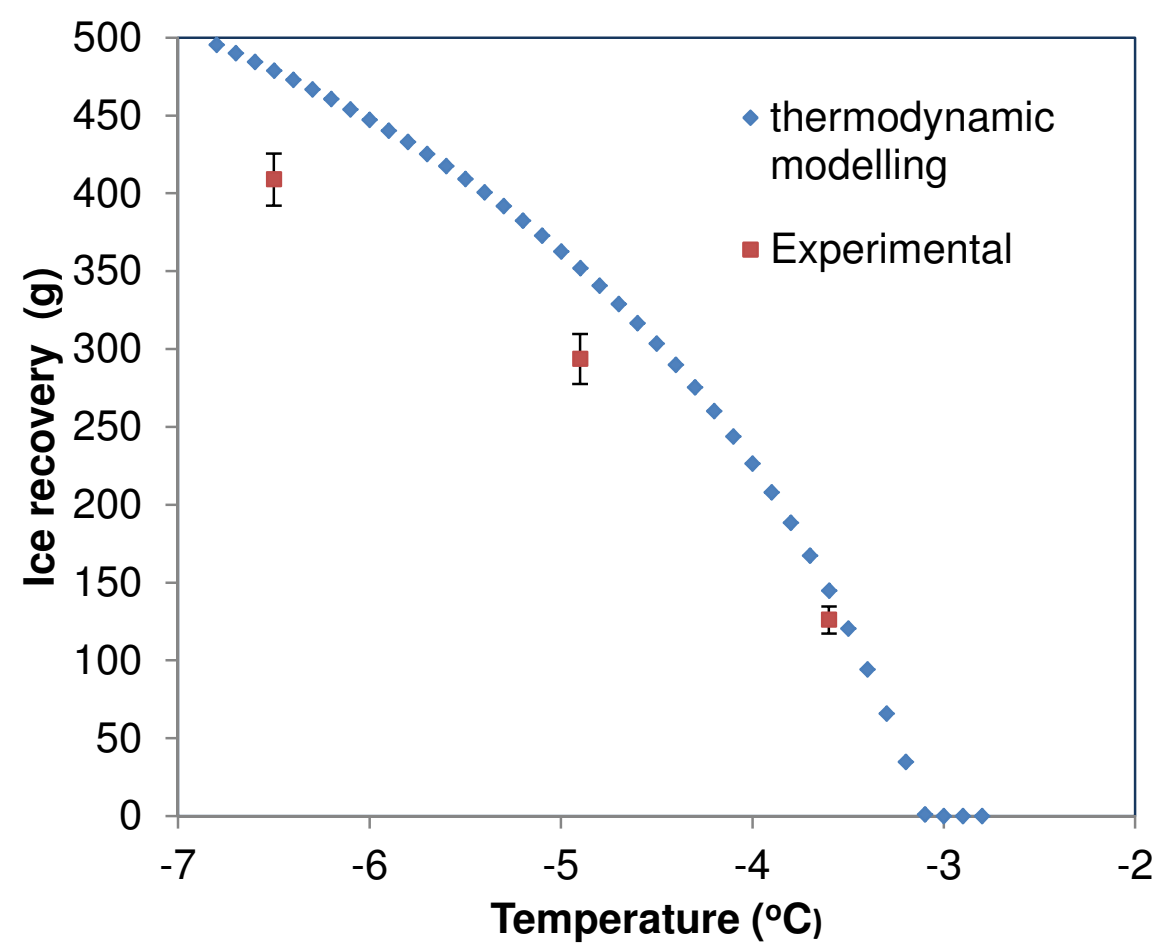

Figure 3: Water recovery (as ice) at different temperatures, error bars show the standard deviation of the mean

The cumulative amount of ice recovery increases with decreasing temperature due to an increasing supersaturation ratio at lower temperatures. At temperature of -6.5 ${ }^{\circ} \mathrm{C}$, the amount of ice recovered is 4099 , which is $42 \%$ recovery. From Figure 3 , it is visible that this less than the recovery from the thermodynamic model, the system only reaches $85 \%$ of the equilibrium amount. As the batch time of 3 hours was experimentally determined as the amount of time required by the system to reach equilibrium, theoretically, the experimental amount recovered should be the same as the predicted value. The loss of mass could be due to melting during weighing and losses during container transfers.

\section{Cumulative recovery of $\mathrm{Na}_{2} \mathrm{SO}_{4} \cdot 10 \mathrm{H}_{2} \mathrm{O}$}

Figure 4 presents the cumulative recovery of $\mathrm{Na} 2 \mathrm{SO} 4.10 \mathrm{H} 2 \mathrm{O}$ as a function of temperature, both from experimental work and thermodynamic modelling. 


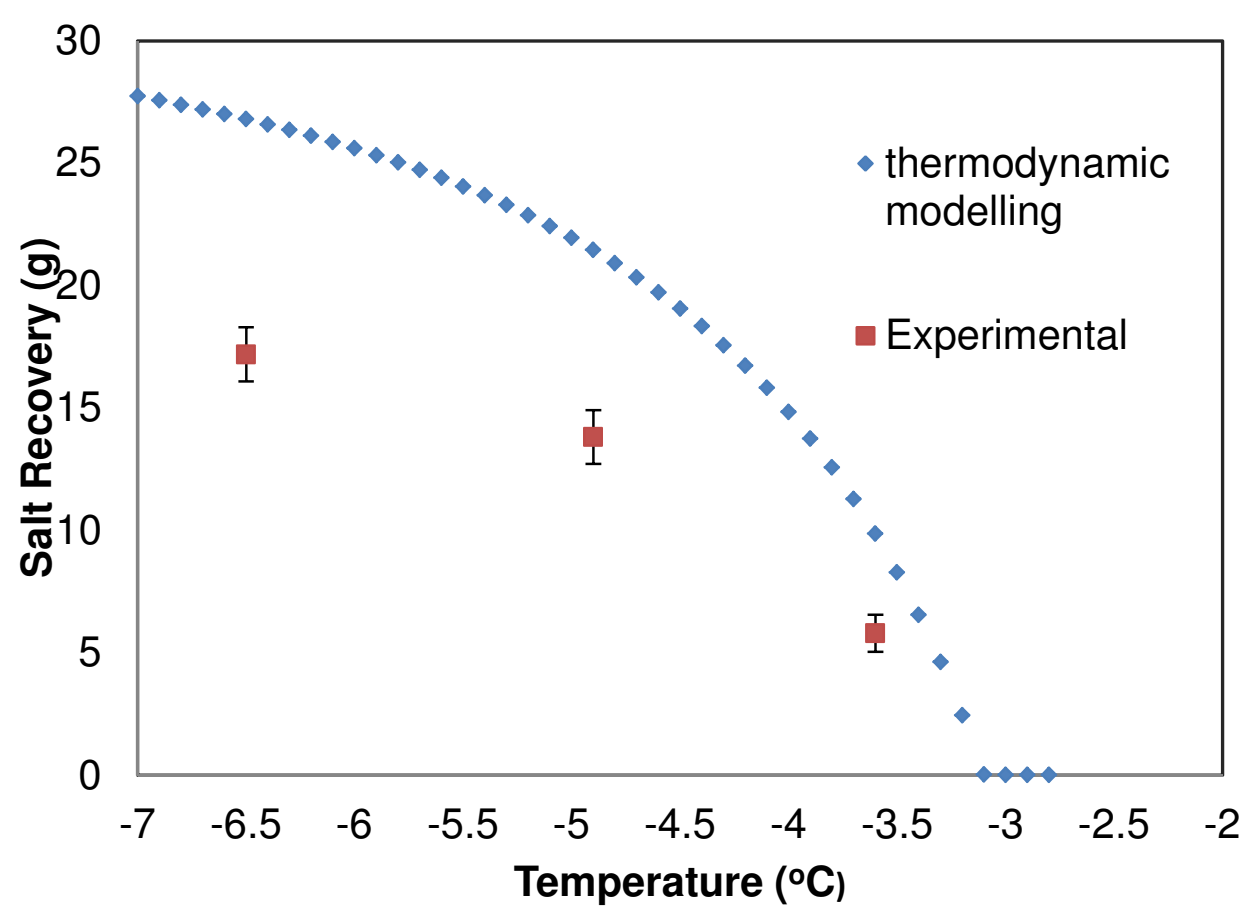

Figure 4: Sodium sulphate decahydrate $\left(\mathrm{Na}_{2} \mathrm{SO}_{4} \cdot 10 \mathrm{H}_{2} \mathrm{O}\right)$ recovery at different temperatures, error bars show the standard deviation of the mean

The cumulative amount of $\mathrm{Na}_{2} \mathrm{SO}_{4} \cdot 10 \mathrm{H}_{2} \mathrm{O}$ is $17.2 \mathrm{~g}$, which translates to a recovery of $51 \%$ of the anhydrous salt. The purity of the $\mathrm{Na}_{2} \mathrm{SO}_{4} \cdot 10 \mathrm{H}_{2} \mathrm{O}$ product was $98 \%$, possible contamination by the mother liquor might have occurred. Washing the product with a sodium sulphate solution would increase the purity of the product but might compromise the amount of salt recovered. The recovery of the salt is limited by thermodynamics, comparing the experimental data with the model data shows that the system only proceeds $65 \%$ towards equilibrium, suggesting a $35 \%$ loss of the product.

Sulphate analysis of the residual mother liquor at $-6.5{ }^{\circ} \mathrm{C}$ shows that there is still 3.39 of $\mathrm{Na}_{2} \mathrm{SO}_{4}$, which has the potential of forming $7.69 \mathrm{~g}$ of $\mathrm{Na}_{2} \mathrm{SO}_{4} 10 \mathrm{H}_{2} \mathrm{O}$. The residual mother liquor analysis shows that $25.8 \mathrm{~g}$ of $\mathrm{Na}_{2} \mathrm{SO}_{4} .10 \mathrm{H}_{2} \mathrm{O}$ have been removed from solution, showing that the experiment actually proceeded $97 \%$ towards equilibrium, suggesting that $8.6 \mathrm{~g}$ of $\mathrm{Na}_{2} \mathrm{SO}_{4} \cdot 10 \mathrm{H}_{2} \mathrm{O}$ was entrapped within the interstitial voids of the ice crystals. The ice crystals tend to form loose aggregates which 
encapsulate the smaller salt crystals and therefore prevent them settling; not only lowering the salt recovery but also decreasing the purity of the ice (Reddy, et al., 2009).

Purity analysis of the ice product at $6.5{ }^{\circ} \mathrm{C}$, showed a purity of $94 \%$ before any washing. A study into the treatment of a reverse osmosis product by (Randall, et al., 2011) reported an ice product of $99 \%$. The ice product from this study is entrapped with $\mathrm{Na}_{2} \mathrm{SO}_{4} \cdot 10 \mathrm{H}_{2} \mathrm{O}$ and also contaminated by the mother liquor. Washing the ice product twice with distilled water at $1{ }^{\circ} \mathrm{C}$ increases the purity of the ice to $99.3 \%$ but results in melting and hence loss of the ice product.

\section{Conclusion}

The technical feasibility of EFC was investigated on a solution stream containing $1.4 \mathrm{wt} \%$ sodium sulphate and $4.5 \mathrm{wt} \%$ sodium chloride. Thermodynamic modelling revealed that the nucleation temperature for ice and $\mathrm{Na}_{2} \mathrm{SO}_{4} \cdot 10 \mathrm{H}_{2} \mathrm{O}$ was $-3.1{ }^{\circ} \mathrm{C}$ and $21.6{ }^{\circ} \mathrm{C}$ for $\mathrm{NaCl}$. As the study was limited to temperatures above $-7^{\circ} \mathrm{C}, \mathrm{Na}_{2} \mathrm{SO}_{4} \cdot 10 \mathrm{H}_{2} \mathrm{O}$ was recovered from solution.

The cumulative recovery of salts and ice increases when the operating temperature is decreased. Sequentially decreasing the temperature and recovering the products, before proceeding to operate to the next operating temperature results in high cumulative recovery of products, as the recovery of products at one temperature is limited by thermodynamics. The recovery of $\mathrm{Na}_{2} \mathrm{SO}_{4} \cdot 10 \mathrm{H}_{2} \mathrm{O}$ at $-6.5^{\circ} \mathrm{C}$ was found to be $51.3 \%(17.2 \mathrm{~g})$, with greater than $98 \%$ purity. The recovery of ice at this temperature was found to be $42 \%$ (409 g), with $94 \%$ purity prior to washing. The amount of salt recovered is $64 \%$ of the recovery predicted through thermodynamic modelling; the ice is $85 \%$ of the predicted value.

Purity analysis of residual mother liquor at the operating temperatures showed $50 \%$ (8.6g) more $\mathrm{Na}_{2} \mathrm{SO}_{4} .10 \mathrm{H}_{2} \mathrm{O}$ should have been recovered at this temperature. As the stream under study is dilute, there is large ice formation resulting entrainment of salt crystals in ice crystals and hence the loss of $33 \%$ loss of the salt formed. Ice purity data 
that could be used to confirm the entrainment of salt crystals is inconclusive due to inconsistencies with the system mass balance.

EFC is technically feasible as it is possible to recover water and a single salt from a ternary system with high purity. However, in order to avoid the large ice formation and improve the settling and subsequent settling of the salt product, the stream should be concentrated, through taking it through staged $\mathrm{RO}$ before being treated with EFC.

\section{References}

Chemguide, 2014. Solid-Liquid Phase Diagramas: Salt Solution. [Online] Available at: http://www.chemguide.co.uk/physical/phaseegia/saltsoln.html [Accessed 2010 2014].

Genceli, F., Gartner, R. \& Witkamp, G., 2005. Eutectic freeze crystallization in a 2nd generation cooled disk column crystallizer for the recovery of MgSO4.12H2O. Journal of Crystal Growth, Issue 275, pp. 1369-1372.

Hussain, I., 2012. Case study of a zero liquid discharge facility in textile dyeing effluents at Tiripur , Hyderabad: Tamilbadu Water Investment Company Ltd..

Lewis, A. et al., 2010a. Novel technology for the recovery of water and solid salts from hypersaline brines; Eutectic Freeze Crystallization, Cape Town: Water Research Commission. 
Myerson, A., Ginde, R. \& Schwartz, A., 2002. Solutions and solution properties, crystal growth and nucleation. In: Handbook of Industrial Growth. Massachusetts: ButterworthHeinemann, pp. 10-50.

OLI Systems, I., 2011. A guide to using OLI Analyzer Studio, New Jersey: OLI Systems Inc.

Parvathi, C., Maruthavanan, T. \& Prakash, C., 2009. Environmental impacts of textile industries.

[Online]

Available at: $\quad \underline{w w w . i n d i a n t e x t i l e j o u r n a l . c o m / a r t i c l e s / f a d e t a i l s . a s p ? / i d=2420 ~}$ [Accessed 20 September 2014].

Randall, D., Nathoo, J. \& Lewis, A., 2011. A case study for treating a reverse osmosis brine using Eutectic Freeze Crystallization- Approaching a zero waste process. Desalination, Volume 266, pp. 256-262.

Reddy, S., Kramer, H., Lewis, A. \& Nathoo, J., 2009. Investigating factors taht affect separation in a eutectic freeze crystallization process. Pretoria, Abstracts of the International Mine Water Conference.

Vaessen, R., 2003. Development of scraped eutectic crystallizers, Delft, Netherlands: TU Delft. 